\title{
The Virtue of Ruin in Machiavelli's
}

\author{
Florentine Histories
}

JACK D'AMICO

We find in Machiavelli's work frequent repetition of a patterned relationship between human and natural orders that he describes in the Florentine Histories as ruin, birth and expansion. ${ }^{1}$ Ruin does not simply precede the birth of cities, it constitutes and creates the very necessity for government, preparing the way by teaching men to heed a founder strong and wise enough to bring about the birth of civil order. ${ }^{2}$ Man is wed to and rises above nature because of an ability to understand disorder and to channel the discords of nature so as to produce ordini. ${ }^{3}$ Machiavelli, as we know, is not a utopian thinker drawn to peaceful seclusion, stasis and natural equanimity. For him nature generates life from cyclical movement and those men of understanding who both see and have the virtu to act are able to convert that energy into lasting orders. In the cycle we find both a necessary, natural limit to what man can do and the opportunity to imitate nature by creating order from disorder. I will explore this central dynamic of Machiavellian thought as it appears in the first half of the Florentine Histories, particularly as related to the virtuous ancient order of sending out colonies. Two important passages from his Discourses provide a preliminary delineation of the way human orders interact with and imitate natural necessity.

In the Discourses I, 1, Machiavelli states, in a typically disjunctive either/or formulation, that men act out of necessity or by choice and that greater virtu arises when choice is less operative. ${ }^{4}$ Though one might expect choice, a component of will, to be a part of virtú, men given the freedom to choose slip toward a natural state of viltà (the psychological equivalent of rovina). However, a superior act of choice or free will on the part of a founder creates orders forcing men to exercise restraint, selfsacrifice, military courage and other requisite virtues of civil life. Order is born from the coincidence of human understanding and social necessity. Men are virtuous when they have suffered and accept a limitation on their freedom to be vile. For Machiavelli the state imitates the necessities of nature (the battiture) $)^{5}$ in such a way as to produce security, for a time, and a 
degree of equality, at least inside the city and within the tensions or humours of discord remaining behind the forms of equal citizenship.

Machiavelli is considering necessity and choice as related to the selection of a site for the founding of a city. ${ }^{6}$ We find there is no unqualified good, or natural good unless mediated (and thus qualified) by human understanding and orders. Utopian sites of fertile amenity where nature is soft and the necessary battiture missing produce laziness (ozio) and prepare men for enslavement. Nor is there unqualified evil since disorder and suffering (even enslavement) prepare the way for the man of strength and brain who founds the city and is assisted in teaching men the hard lessons of sacrifice for the common good by their experience of evil.

Thus the birth of a state must be seen in relation to the ruin that preceded and will follow, more or less quickly. Nor can the founding be divorced from augmentation. A sterile, hard natural setting necessitates virtuous self-sacrifice and is good because greater virtu exists where choice is limited (la elezione ha meno autorità, I, 1, p. 127). But ironically, election (elezione/eleggere) of a fertile setting and the imposition through laws of the necessity to act virtuously is best when the state will expand, because the productivity and populousness can be directed outward and made the basis for augmentation, as was the case with Rome. ${ }^{7}$ Harsh conditions holding men to virtu work best for the closed, self-contained republic when men are constrained by nature to be industrious and where the natural sterility reduces the occasion for discord and produces that self-restraint and poverty characteristic of the republican character. With the expanding state there is greater opposition, a more dynamic interaction between the soft site and the tough laws. The laws and customs of the closed republic seem to grow more out of the nature of the site and would be preferable were it not for the fact that the harshness and inequality of nature is reflected in man. The natural fact that men and states seek to dominate others necessitates self-defense (assicurarsi) by means of strength (la potenzia) that only comes from a productive and populous site.$^{8}$ Therefore, human knowledge, the understanding of this very state of nature, requires that law be used to effect necessary constraint and guard against softness. Choice of an edenic setting for Machiavelli leads to aggressive self-defense rather than peace; we flee the harshness of nature only to have it recreated in the laws and customs of the city that must guard against l'ozio.

The primary order imitating the harsh constraint of a natural setting is military training. Expansion cannot take place without strength of arms ( $l a$ potenzia), and expansion-commanding others-is the best form of selfdefense-protection against being commanded by others. Thus, expansion protects the city from ruin. But, as we shall see, it is also tied to those internal discords arising in a potent, populous city-state, like Rome, that chooses to arm the people in order to expand. Those discords may, of 
course, eventually lead to ruin.

The question of whether or not the state will undergo augmentation rests with the founder and his understanding of the natural condition; if we are constrained by the necessity to be strong (la potenzia), the dark nature of man and experience (battiture) teach that we not only form states but choose a base and create laws that will lead to virtuous growth. Utopian softness and productivity (what Machiavelli calls la ubertà or l'amenità) is good only if combined with those human orders that guard against laziness. To put this another way, the softness of nature is an illusion, for the state is born from ruin, and the threat of ruin a worldly wise man never forgets.

We need to consider one other delineation of the problems of nature and orders in the Discourses II, 8 before turning to the Florentine Histories. Machiavelli contrasts wars of expansion undertaken by a republic or principality by choice, to satisfy ambition or a desire for glory, and wars waged by a people forced to migrate by famine or an oppressive war (cacciati dalla necessità). ${ }^{9}$ Necessity and choice are again compared-from the viewpoint of those assaulted a war of choice is less terrifying because the occupying force is not driven to replace the inhabitants. Such warfare is directed against the leaders of the state and will leave much else intact; ambition and glory can be satisfied by gaining control over rather than extirpating conquered peoples. A war of necessity (migration) is most terrifying because it produces total ruin, a violent and complete change in orders. In his example, a war of oppression, which may be undertaken by choice, imitates famine, the natural necessity, by forcing the oppressed to migrate. We have a glimpse of the real fact of injustice and dislocation productive of the ruin from which new states arise.

There is no escaping the cycle of ruin, birth and augmentation, except, perhaps, in the self-sufficient republic strong enough to defend itself without expanding. ${ }^{10}$ That republic, founded on harshness, reformed by periodic returns to its natural base, upheld by good laws and embodied in strength of character may be Machiavelli's version of Eden. His worldly wise preference for a productive site creates the opportunity for virtu but the election and consequent direction of the state outward also seems a self-fulfilling prophecy since expansion both defends against and demonstrates the need men and states have to command others. Perhaps the key distinction is between those states that absorb gently and the oppressive wars that drive out inhabitants and represent as harsh a necessity as famine. As we see in the Florentine Histories (I,5), a form of migration by northern peoples, combined with the decay of Rome, led to a most painful example of collapse and change ushering in the modern world of viltà.

If human orders are based on an understanding of nature, they both 
oppose and imitate, control and use, the fundamental inequalities and periodic returns to chaos that continually drive things of this world. Machiavelli begins the Florentine Histories with the description of an order utilized by northern tribes threatened by over-population. ${ }^{11}$ To guard against famine they send off a third of their citizens, chosen by lot, to seek their fortune. Election, in this instance, is used to preserve a populous state and its fertile site, but not to expand. Those who migrate carry with them civic forms, such as the inclusion in each third of nobles and commons, rich and poor, as well as customs and language. But they do not take control of governments as representatives of the homeland. They must take on a new civic identity as they supplant and mingle with other peoples. Preserving the common good ( $i$ bene patrii) for those who remain behind is an act of virtu necessitated by a law that protects the state against the dangers of famine and over-population. ${ }^{12}$ Fear of famine, like the fear of being conquered, can lead to aggressive action, the movement outward that contributes to the collapse of Roman orders, precipitating a period of total ruin when changes in laws, customs, morals, religion, language, dress and names take place $(I, 5$, p. 81). From this disorder cities such as Florence are born. Northern tribes and the ancient Romans both understood nature and made use of orders to preserve or augment the state.

For Machiavelli the primary weakness of the states born in modern Europe is their lack of military virtu. He returns to the theme of expansion at the end of Book I, asserting that expansion will not occur until modern men understand and embody in law the necessity that forces virtuous action. Machiavelli speaks of conditions inviting oppression or collapse (oziosi principi e di queste vilissime armi, I, 39, p. 136). Just as famine or oppressive war represents a threatening necessity that may at any time force barbarians or tyrants to invade, so the desire to replace vilta with true glory, or even simple ambition, requires that arms be used both to protect and to direct the energies of the state outward. Modern states, however, neither expand nor, most paradoxically, do they quite collapse.

When in the introduction to Book II Machiavelli again turns to the failure of modern states to imitate the ancient order of using colonies to build outward (edificare di nuovo), he states that by using colonies a prince or republic can secure conquered or deserted regions (o vintio vuoti). Conquest resulting from choice may, it now appears, produce change in more than the leaders of a conquered people. After his denigration of modern viltà, Machiavelli is emphasizing the interdependence of virtù and human understanding. Colonies help absorb regions newly conquered by a prince, rendering them secure by planting there men faithful to the prince, and they make possible a more equitable distribution of population within a state over both fertile and infertile areas. Machiavelli underscores the capacity for good orders to provide balance where nature cannot. ${ }^{13}$ As with Venice 
(a prime example of a closed republic) and $\mathrm{Pisa}$, the confluence of a people and their industry can transform an inhospitable site into a flourishing state. On the whole, however, he underplays the rôle of states driven to virtú by necessity (oppression and infertile sites), though Pisa is called populous and strong. The major thrust of the introduction is that the order represented by sending out colonies exists in a state strong enough to conquer or to expand. Security and development are made to seem dependent on election and on human understanding, on a prince's desire for glory or a republic's desire for praiseworthy orders. Growth that is not forced by harsh natural conditions is more difficult precisely because it is dependent on human understanding or laws, but for that reason deserving of praise.

Machiavelli ties his theoretical introduction to the founding of Florence and its early expansion. The shift from Fiesole's mountain site to the plain where Florence is set between the foot of the mountain and the river took place to create a more accessible place for the market (Machiavelli uses the word commodita which I connect with amenità of sites in the Discourses $\mathrm{I}, 1)$. This move is symptomatic of a general condition in ancient Italy brought on by the internal security resulting from Roman military success. With political amenità population multiples and a movement takes place from harsh to more commodious sites, rather than the opposite redistribution from populous to deserted areas Machiavelli had described in his introduction. Military success produces an internal slackening of necessity and a drift away from the harsher sites because, as Machiavelli often says, men must be forced to confront difficulties. ${ }^{14}$ Comparing the theoretical introduction and the historical example of the founding of Florence, we recognize an inherent contradiction in Machiavelli's treatment of the ruin, birth and augmentation of states. If military virtu and successful expansion represent the way to bend men to necessity while drawing on fertile sites for populous strength, that very success creates internal problems. With security from attack comes a movement within the state toward less harsh sites and a greater concern with goods (the market). Having more, men move from the mountain to the plain, from military virtù to commerce. In the Discourses it seems that selection of a fertile site is a precondition for populousness and expansion, while in the Florentine Histories toughness develops from initial scarcity and produces military victories, an extension of the frontiers of the state and only then a drift toward internal amenita.

Another significant result of security and the slackening of necessity is political discord, for Florence is founded during the period of civil war. Machiavelli returns to this important subject in Book III, for expansion brings with it an internal variation on the problem of men seeking to command one another. While expansion protects citizens from the threat of invasion, it creates the occasion for conflict between nobles and commons over the question of who should command and to what extent one party 
should dominate another. As we shall see, the very necessity to arm the populace in order to expand creates the internal, reciprocal civil war, a softening at the center of the state. These discords too can be mediated by good orders, as was the case with the wise or fortunate Romans. Thus, the founding of Florence as a colony from Fiesole aptly represents the greatness of Rome, using orders to expand, maintaining both virtu and security at home. Though no state can escape the cycle of expansion and collapse, human industry and understanding can do much. What is needed, in a symbolic sense, is a movement from the plain back to the mountain, from soft to demanding conditions, from commerce to military virtue.

Florence, like many of the states born from the collapse of the Roman Empire, reached the high point of its development early and never became strong enough to expand or send out colonies; it does not reach the state of lo augmento. ${ }^{15}$ The fact that internal discord weakened Florence in a way not true of Rome invites an important comparison by Machiavelli between things ancient and modern.

In his introduction to Book III Machiavelli identifies the serious and natural antagonism between populace and nobles as the cause, the humor feeding all perturbations in the state. Inequalities of class seem as much a part of nature as the inequalities of site. Like all dangers, these natural antagonisms threaten but also provide the occasion for virtu and industry within the state. The key distinction between Rome and Florence, with respect to discord, is that Roman antagonism resulted in disputation rather than the bloodshed and exile characteristic of Florence. ${ }^{16}$ Orders can mediate discord to make it serve the common good. Roman institutions seem to derive energy from the natural state of opposition between classes because Rome accepted friction as the price for maintaining an armed populace and thus used its orders to control, for a time, external and internal threats. As Machiavelli says in his poem "Dell'Ambizione," a wellordered state uses the furor of its citizens not against itself but against outsiders (l'esterna gente). ${ }^{17}$ Behind this interaction between the forces of nature and the orders of the state is a choice, for the closed republic does not expand and can avoid internal discord and do without an armed populace.

Florence has the worst of both worlds. With the commodità of its founding, the city is populous and rich but lacks the military toughness needed to expand. The populace is not only a participant in government but becomes the dominant class, though unarmed. We do not see the balance of opposing forces that existed in Rome where the populace achieved some legitimate means of expressing its ambition but did not eliminate the opposition. In Florence a perverse imitation of nature, a cancer of sorts, afflicts the state since parties proceed to exterminate one another; instead of directing the furor outward, it turns it inward against the body politic. ${ }^{18}$ 
However, Machiavelli ends his comparison between Rome and Florence by noting that the cycles of order and disorder can never be stopped. Faction did eventually afflict Rome when the long simmering issue of the agrarian law finally led to the creation of parti, a turning from magistrates to private interest (rimedi privati) and the outbreak of civil war. ${ }^{19}$ The pride of the nobility, their desire to preserve wealth (fostered by the very expansion of the state), produced conflict with the commons and the emergence of Caesar as champion of the popular party. Republican institutions were lost and thus Rome, as Machiavelli says in the Florentine Histories III, 1, was overcome by a prince. On the other hand, Florence cannot be transformed into a principality; it needs (or Machiavelli invites) the reforming virtu of a lawgiver. ${ }^{20}$

Feisty humors within Rome fed, for a time, both discord and the expansion of the state from its populous base. Election of a site is analogous, in the myth of the cycles of ruin, birth and expansion, to the election of a way and of orders. In the opening of the Discourses Machiavelli tells us that discovering orders is like discovering new lands; orders chart the course, the direction of the state. A wise giver of orders must choose right and to do so must know the given setting or condition of the state, the place, productive or infertile, and the consequent nature or disposition of the people who settle there under commodità or the sterner necessities. In what Machiavelli says about the need for reform in Florence we can see another dimension of the relationship between natural necessity and human understanding. ${ }^{21}$ Orders cannot be imposed upon the substance (materia) of a societyFlorence will not accept a prince. In Rome there was a fortunate sequence in the founding, the creation of orders, the use of an armed populace for expansion and the long continuing virtù feeding and being fed by the dynamic growth of the state. In the Florentine Histories Machiavelli uses the tyranny of the Duke of Athens (Gualtieri di Brienne) to show that new orders must grow from an understanding of materia. While the discontentted (grandi and plebe) are willing to accept the Duke as prince (II, 33, p. 190), some to destroy the popolo and others for no better reason than to escape private debts, representatives of the middle class (dei signori) attempt to persuade Gualtieri that he will be unable to retain power because the city will not voluntarily give up its liberty(II, 34, p. 192). They argue that the violence needed to reshape the city requires the impossible union of good and bad in one man. Because he has not properly assessed the character of the city (the materia), his rule amounts to a foreign invasion of French customs and the mere destruction of traditional forms without a rebuilding of new orders (II, 36). The Duke maintains that the faulty orders of the city, the very divisions that caused him to be called in, have destroyed its liberty.

The Duke fails to identify his interests with the city and he may be guilty 
of speaking too openly of the Florentine divisions, for we can see in the Florentine Histories that a restructuring of ordini agreeable to the character of the state requires not only understanding but a noble lie. In a republic like Florence it must appear that differences are not so great that liberty has been lost; the truths of basic inequality or division must be concealed for the common good. Though the way is open for a prince astute enough to build from and merge his interests with Florentine traditions, Machiavelli emphasizes republican reform through a lawgiver, perhaps because no viable princely candidate existed at the time of his writing. ${ }^{22} \mathrm{He}$ seems to leave open the question of whether Florence should move toward the closed state, or toward expansion, though his general argument looks towards military virtu and augmentation as the answers to viltà.

In Book III Machiavelli presents two unnamed speakers who address the problem of division within Florence-one represents a moderate warning not to allow private ambition to destroy the public good(III, 5, p. 218), the other a more radical solution and a revelation of the most fundamental division of nature(III, 13, p. 237). The first speaker dramatizes the distinction between Florence and Rome; by reviewing the multiplication of faction in Florence, he demonstrates in detail the general principle established in the introduction to Book III. Corruption follows when some form of necessity no longer forces men to observe the common good. After the fall of the Empire, no such necessity existed to prevent the slide toward private interest and ozio (slackness) in the newly formed city-states. Machiavelli places in this speaker's mouth an important observation about modern states; because fear of God is spent, oaths and fidelity extend no farther than utility. ${ }^{23}$ Christian religion has not created inherent virtuousness of character (or materia) and after the collapse of the Empire there are no orders that might correct abuses; as a result, young and old are corrupt, the bad are industrious and the good, foolish, the appetite for true glory lost, and states have degenerated into discord and division.

The purpose of the speaker's survey of faction is to encourage reformunderstanding of viltà, the sad spectacle to which the modern historian must descend, can yet be profitable, for a wise lawgiver can restore the primacy of public interest through a change in orders. There must be some necessity, the force that accompanies understanding, if men are to be turned from self-interest and folly to self-sacrifice and virtù. And there must also be faith, not of the Christian kind, but rather the kind Machiavelli tries to arouse in the Proem to Book II of his Discourses-the belief that modern man can discover and implement new forms and orders that will rival and may surpass the ancients. Machiavelli knows, of course, that men are more apt to preserve a pre-existing order than to know how to find a new one (III, 6, p. 223).

Our first speaker explains faction and rampant self-interest as the result 
of specific historical circumstances that can be understood and corrected by human industry; the reform he calls for avoids ruin, achieving rebirth through new orders. Only a rare combination of force and belief(the noble lie that says division is an accident of history) will cause self-interested citizens to heed this advice. Our second speaker reveals the naked fact of greed and oppression under the clothing of civilized society. During tumults caused by what Machiavelli calls l'infima plebe, a man of audacity and experience speaks for the politically disenfranchised and those small guilds not represented in the government. ${ }^{24} \mathrm{He}$ exposes evils rooted in the very nature of man.

Encouraging the rebels to fight on because they have nothing to lose, the unnamed speaker reveals that society imitates the essential inequality of nature-the strong enslave the weak, the clever outsmart the foolish. His premise is that necessity teaches them to push on. Having taken up arms they have gone too far to retreat toward compromise or reform, nooses have already been strung, and the ultimate justification for their continuing the fight is that nobility is an illusion, the common good a noble lie serving the interests of the powerful. All men stripped of their clothing are the same, equally ignoble descendants of fallen Adam. ${ }^{25}$ Behind social forms lurks the real fact of dog-eat-dog. ${ }^{26}$ Force and the ability to seize the moment will result in victory, and the victorious, whatever their methods, emerge with honor and security. This audacity is prudent when considered in the context of necessity. Faction carried to its logical extreme returns the city to a state of nature or ruina, the furor turned in upon men in the fire and spoliation of one group devouring another. In the context of this natural condition reform is impossible and, therefore, the speaker encourages his followers to fight for what the rich and powerful have, to change clothes and places with them. Power will then be translated into justice. Once this fact has been revealed the rebels have nothing to lose- not even the state itself-for it can be reborn from ruin in their own image. For those men who understand the underlying fact of natural injustice, the original premise for the state (rovina) always exists. Thus the occasion for the founding of a new state by a man of brain and strength merely makes explicit, through revolt, what is usually hidden. That founding requires leadership and battiture, for men will only risk death after they have suffered and come to feel there is nothing to lose by fighting on.

Like the state that must expand to remain secure, conquering or dislocating other peoples as it pushes out armed forces and colonies, a party must destroy the city in order to survive and triumph. In this state of nature, where necessity equals survival, l'esterna gente becomes the opposing faction. When ordini fail to provide the man-made necessity that restrains self-interest and creates respect for the common good, this furor and the stripping away of appearances teach men, though painfully, both why they 
need the state (to escape discord) and why they must flee viltà and act with virtu.

If disorder provides the occasion for a man of strength to create orders conducive to virtu, then from the ashes of turmoil a new order will arise. Reform and the emergence of a new state after ruin are closely related: men can learn from a wise lawgiver, accepting self-sacrifice and virtuous respect for the common good because they fear the collapse of the state, or because they experience that collapse. But in either case, only some sense of necessity will create virtu; men must understand the real and terrifying fact of their nature (gli uomini mangiono l'uno l'altro) before they will accept reform (la benignità delle leggi). ${ }^{27}$ Order depends upon disorder, perceived or experienced.

The peculiar failure of the modern state is that it has escaped necessity and for that very reason will never achieve true glory or praiseworthy orders. The viltà Machiavelli identifies with his city is not the product of corruption alone, for corruption, decay, change and inequality are always present in nature. Failure to create orders necessitating virtue is a failure of understanding prompted, in part, by the very success of the Renaissance state where vilta is endemic because men are insulated from battiture. Florentines will not accept a prince, even if there were a man wise enough to understand the materia and identify his self-interest with the common good, and the founding of the city, the commodita extending through its mercantile rather than military virtue, renders it deaf to the appeal for reform.

When Machiavelli presents the father of the modern Florentine state, he makes it clear that the virtu of a Cosimo thrives on the avoidance of necessity; it flourishes in the private world of amenita and is not embodied in the creation of new orders. We are told that Cosimo cares about public life (IV, 26, p. 308 \& IV, 16, p. 292), but he is governed by prudence and extends his influence through the manipulation of men (amici \& par tigiani). ${ }^{28}$ In the Discourses the creation of partisans is identified with corruption in a republic and with the triumph of private over public interest. ${ }^{29}$ A man such as Cosimo has a partisan following precisely because he can protect men from the force of the law and in so doing create a secure position for himself and his family. This subtle disorder of the modern state does not lead to the rovina preceding and preparing men for rebirth. Cosimo is the greatest of unarmed citizens (VIII, 5, p. 458), but his power does not extend to the creation of those orders necessitating virtu and sacrifice. He is in every sense the father of a city-state rich, populous and yet incapable of achieving what Machiavelli considers true glory. His ability to sustain Florence shows his greatness and his failure, for he represents modern man's ability to overcome nature, avoiding collapse and the natural cycle of decay and rebirth, while failing to imitate nature and to 
create a new order from disorder.

Cosimo has studied the state not in order to reform it but to know how to use and manipulate the men within it; he carries faction to its logical conclusion in a much more subtle way than the audacious speaker of Book III because his actions are always clothed in the legitimate, though inherently corrupt ways of the city. Avoiding open conflict, he nevertheless succeeds in not only sustaining his party but in decisively conquering the opposition.

Through.Niccolò da Uzzano, Machiavelli clarifies Cosimo's method and underlines the clever way his power is masked. What leads the opposition to suspect Cosimo and to fear his ambition is the use of wealth to control individuals, magistrates and even condottieri while breaking no laws. For that reason he cannot be openly attacked. Rinaldo degli Albizzi repeats the same accusation, and, when he is finally defeated and Cosimo recalled from exile, Rinaldo leaves Florence calling it a city where laws count for less than men. ${ }^{30}$

Cosimo triumphs but does so without arms, without the painful necessities that create virtù. He understands Florentine materia and exploits it, using wealth to create a private power base; his methods suit the founding of Florence, the market in the plain, for Cosimo is not the wise, stern lawgiver who will direct the city back to the harsher virtues of the mountain.

Unlike Rinaldo, Cosimo is not the kind of man whose actions might lead to the total collapse of the state or its violent overthrow. But the introduction to Book $V$ raises the provocative question of whether the ruin of a state is altogether a bad thing. A variation on his conception of nature, the anacyclosis Machiavelli describes in Book $\mathrm{V}$ recalls the natural disequilibrium of sites, the opposition between scarcity and abundance, nobles and populace, the wise and the foolish, servitude and license. But the emphasis in his introduction is on a continuous, organic process of change that takes states, though painfully, through disorder to order. His presentation of this cycle may provide a stern warning as preparation for reform, or anticipate the natural collapse preparing the way for rebirth in a less benign but no less effective manner. Above all, Machiavelli opposes the failure to create meaningful orders, whether for a republic or principality, and the subverting of the public good by men, like the Medici, of great but unfulfilled virtù.

Ultimately one of the most puzzling things about Machiavelli is the antagonism in his work between the rôle of the reformer-the man who would save the state from collapse, giving his very soul for it-and the man who recognizes that the battiture, whether of a prince or of natural, cyclical ruin may be better for the state in the long run. There is a serious conflict between the warnings meant to encourage reform so as to avoid internal 
collapse, and his repugnance for a via di mezzo that will merely perpetuate apparent splendor at the expense of true orders. Although one feels Machiavelli to be closest in spirit to the wise and strong lawgiver who would sweep away the viltà of his city and return its early promise, he will also accept the orders that come either from a man of true virtú, even a prince, or from the painful teachings of ruin that will precede the birth and, perhaps, the expansion of his city.

\section{Canisius College}

\section{Notes}

1 Istorie fiorentine, ed. Franco Gaeta (Milan: Feltrinelli, 1962), I, 5, p. 81: Da questo nacque la rovina, il nascimento e lo augumento di molte città.

2 Discorsi, ed. Sergio Bertelli(Milan: Feltrinelli, 1960), I, 2, p. 131. See Leo Strauss, Thoughts on Machiavelli (Chicago: University of Chicago Press, 1958), pp. 245-252 and my essay "Order from Disorder. Machiavelli on Cyclicity," forthcoming in The Canadian Journal of Italian Studies.

3 On ordini Frederico Chabod, Machiavelli and the Renaissance (Cambridge: Harvard University Press, 1958), p. 96; J.H. Whitfield, "On Machiavelli's Use of Ordini," in Discourses on Machiavelli (Cambridge, Eng.: Heffer, 1969), p. 152; Felix Gilbert, Machiavelli e Guicciardini (Turin: Einaudi, 1971), p. 40; Neal Wood, "The Value of Asocial Sociability," in Machiavelli and the Nature of Political Thought, ed. Martin Fleisher(New York: Athenaeum, 1972), p. 289; and J.G.A. Pocock, The Machiavellian Moment (Princeton: Princeton University Press, 1975), p. 167.

4 Discorsi I, 1, p. 127.

5 Istorie fiorentine, V, 1, p. 325: Vengono pertanto le provincie per questi mezzi alla rovina: dove pervenute, e gli uomini per le battiture diventati savi, ritornono, come è detto, all'ordine, se già d'una forza estraordinaria non rimangono suffocati.

6 Strauss, pp. 278-281. See Harvey C. Mansfield, Jr., "Necessity in the Beginnings of Cities," in The Political Calculus, ed. Anthony Parel (Toronto: University of Toronto Press, 1972), p. 211.

7 Discorsi I, 1, p. 127: E quanto a quell'ozio che le arrecasse il sito, si debbe ordinare che a quelle necessità le leggi la coetringhino che il sito non la coetrignesse....

8 Ibid.: Pertanto non potendo gli uomini assicurarsi se non con la potenzia, è necessario fuggire questa sterilità del paese, e porsi in luoghi fertilissimi....

9 Discorsi, II, 8, p. 297.

10 See my "Three Forms of Character. Virtù, Ordini and Materia in Machiavelli's Discorsi," Italian Quarterly, 22 (1981), 9.

11 On structure in the Istorie see Felix Gilbert, "Machiavelli's Istorie Fiorentine: An Essay in Interpretation," in Studies on Machiavelli, ed. Myron P. Gilmore (Florence: Sansoni, 1972) and Harvey C. Mansfield, Jr., "Party and Sect in Machiavelli's Florentine Histories," in Machiavelli and the Nature of Political Thought.

12 Istorie, I, 1, p. 72: e le due parti sgravate del terzo di loro si rimangono a godere $i$ beni patrii.

13 Istorie, II, 1, p. 138: E perché la natura non può a questo disordine supplire, è necessario supplisca la industria....

14 Istorie, II, 2, p. 139: Perché gli uomini non si mantengono mai nelle difficultà se da una necessità non si sono mantenuti. ...

15 The date Machiavelli gives is 1298, Istorie, II, 15, p. 160: Né mai fu la città nostra in maggioree piú felice stato che in questi tempi, sendo di uomini, di ricchezze e di riputazione ripiena.... See Daniel Waley, "The Primitivist Element in Machiavelli's Thought," JHI, 31 (1970), 97. 


\section{4 / Renaissance and Reformation}

16 Istorie, III, 1, p. 212: perché le inimicizie che furono nel principio di Roma intra il popolo e $i$ nobili, disputando, quelle di Firenze combattendo si difinivano; quelle di Roma con una legge, quelle di Firenze con lo esilio e con la morte di molti cittadini terminavono....

17 Il teatro e tutti gli scritti letterari, ed. Franco Gaeta, (Milan: Feltrinelli, 1965), 11. 94-99.

18 On healthy conflict see Discorsi, I, 4 and III, 37 and G.S. Rousseau, "The Discorsi of Machiavelli: History and Theory," Cahiers D'Histoire Mondiale, 9 (1965), 147. Cf. his comments on Florence Discorsi, I, 49, p. 242.

19 Discorsi, I, 37.

20 Istorie, III, 1, p. 213: E dove Roma, sendosi quella loro virtù convertita in superbia, si ridusse in termine che sanza avere un principe non si poteva mantenere, Firenze a quel grado è pervenuta che facilmente da uno savio datore di legge potrebbe essere in qualunque forma di governo riordinata.

21 On the problems of granting or seizing extraordinary powers (vie istraordinarie or autorità istraordinaria) see Discorsi, I, 34, 35 \& 40 and on materia I, 16 \& III, 8. "On the Duke of Athens," Donald Wilcox, The Development of Florentine Humanist Historiography in the Fifteenth Century (Cambridge: Harvard University Press, 1960), p. 48; Peter E. Bondanella, Machiavelli and the Art of Renaissance History (Detroit: Wayne State University Press, 1973), p. 102; and Alfredo Bonadeo, "The Role of the People in the Works and Times of Machiavelli," Bibliotheque D'Humanisme et Renaissance, 32 (1970), 365.

22 In his Discursus florentinarum rerum post mortem iunioris Laurentii Medices, Machiavelli answers those who say Florence needs the strong leadership of a prince to overcome faction by describing the nature of the city (materia) as being better suited to a republican form and, echoing the Discorsi, I, 10, says those men who reform states are, after Iddii, most praised; see Arte della guerra e scritti politci minori, ed. Sergio Bertelli (Milan: Feltrinelli, 1961), pp. 265 \& 275. On princely candidates see Carlo Dionisotti, Machiavellerie (Turin: Einaudi, 1980), p. 393.

23 Istorie, III, 5, p. 219: É perché in tutti il religione e il timore di Dio è spento, il giuramento e la fede data tanto basta quanto l'utile....

24 For the nobles Machiavelli uses the terms nobili, grandi or ottimati, as opposed to their political opponents il popolo, while outside the political system we find the plebe and popolo minuto. See Alfredo Bonadeo, Corruption, Conflict, and Power in the Works and Times of Niccolo Machiavelli (Los Angeles: University of California Press, 1973), p. 103 and Gennaro Sasso, Studi su Machiavelli (Naples: Morano, 1967), p. 153.

25 Istorie, III, 13, p. 237: perché tutti gli uomini avendo avuto uno medesimo principio sono ugualmente antichi, e dalla natura sono stati fatti a uno modo. Spogliateci tutti ignudi, voici vedrete simili....

26 Ibid.: di qui nasce che gli uomini mangiono l'uno l'altro, e vanne sempre col peggio chi può meno.

27 Istorie, III, 5, p. 223. On reform cf. Discorsi, I, 18 \& 34, and III, 1.

28 On Cosimo see Maria Marietti, "Machiavel Historiographe De Medicis," in Les Ecrivains et le pouvoir en Italie a l'epoque de la Renaissance, ed. André Rochon (Paris: Sorbonne Nouvelle, 1974), pp. 105 \& 111; Bonadeo, Corruption, p. 11; Dionisotti, p. 398; Alison M. Brown, "The Humanist Portrait of Cosimo D'Medici, Pater Patriae," JWCI, 24 (1961), 186-214; and my "Love and Fear in Machiavelli's Discorsi," Il Politico, 45 (1980), 432.

29 Discorsi, I, 35 \& III, 22 \& 28.

30 Istorie, IV, 27, p. 311 (Niccolò) \& IV, 33, p. 323 (Rinaldo). 